University of Nebraska - Lincoln

DigitalCommons@University of Nebraska - Lincoln

Proceedings of the Fourteenth Vertebrate Pest

Conference 1990

Vertebrate Pest Conference Proceedings

collection

March 1990

\title{
CONTROLLING VERTEBRATE ANIMAL DAMAGE IN SOUTHERN PINES
}

Jeffrey J. Jackson

Extension Wildlife Specialist, Cooperative Extension Service, Extension Forest Resources

Follow this and additional works at: https://digitalcommons.unl.edu/vpc14

Part of the Environmental Health and Protection Commons

Jackson, Jeffrey J., "CONTROLLING VERTEBRATE ANIMAL DAMAGE IN SOUTHERN PINES" (1990).

Proceedings of the Fourteenth Vertebrate Pest Conference 1990. 44.

https://digitalcommons.unl.edu/vpc14/44

This Article is brought to you for free and open access by the Vertebrate Pest Conference Proceedings collection at DigitalCommons@University of Nebraska - Lincoln. It has been accepted for inclusion in Proceedings of the Fourteenth Vertebrate Pest Conference 1990 by an authorized administrator of DigitalCommons@University of Nebraska - Lincoln. 


\section{CONTROLLING VERTEBRATE ANIMAL DAMAGE IN SOUTHERN PINES}

JEFFREY J. JACKSON, Extension Wildlife Specialist, Cooperative Extension Service, Extension Forest Resources, The University of Georgia, Athens, Georgia 30602.

ABSTRACT: Certain mammals and birds may damage or destroy southern pines, causing economic losses in intensively cultured areas such as seed orchards and nurseries. Mammal pests may eat seeds; tunnel, dislodging seedlings, or chew on roots; or girdle, debark, or sever stems or branches. Bird pests may eat seeds or excavate holes in the tree trunks. The first important step is to identify the pest(s) from the damage left behind. Thereafter, various control options-from using traps and repellents to altering habitat-are available.

Proc. 14th Vertebr. Pest Conf. (L.R. Davis and R.E. Marsh, Eds.) Published at Univ. of Calif., Davis. 1990.

\section{INTRODUCTION}

Over 20 species of mammals and birds can cause economic losses to intensive pine culture in nurseries or seed orchards. Indeed, published literature on most wildlifedamage problems is scanty, and the value of losses is not well documented. This paper aims to familiarize nursery personnel (and foresters) with the species that damage southern pines, to identify the type of damage, and to summarize currently available legal controls. The number of potentially destructive animal species in such areas is higher than in stands of outplanted trees because the value of seeds and seedlings is greater per unit area.

Potential wild mammal pests include among others: voles (Microtus spp.), field mice (Peromyscus spp.), cotton rats

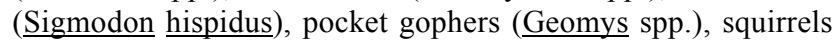

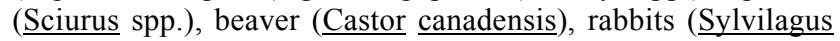
spp.), armadillos (Dasypus novemcinctus). whitetail deer (Odocoileus vjrginianus), and moles ( $\underline{\text { Scalopus }}$ aquaticus). Domestic mammal pests include feral hogs, cows, horses, and perhaps others.

Certain birds, for example, evening grosbeaks (Hesperiphona vespertina) and red-winged black birds (Agelaius phoenicieus). eat seeds from cones. Seeds fallen to the ground, or seeds sown in seedbeds, may be fed on by a great number of species, especially finches. A woodpecker, the yellow-bellied sapsucker (Syphrapicus varius), may damage bark of live trees. Other woodpeckers may excavate holes in bark of trees infested with beetles. Large birds, such as hawks and crows, occasionally perch on small trees and break leaders or branches. Bird damage, unlike mammal damage, often cannot be identified as to species. This is particularly true of seed losses and damage to branches and leaders.

\section{DIAGNOSIS OF DAMAGE Terminology}

Various terms describe what vertebrates do to trees or to each other. Predation refers to one animal eating another. Depredation pertains to animals destructively feeding on seeds, grains in ear, or fruits. Predation is sometimes used by foresters when they mean depredation. Normally predation pertains to one animal eating another. Damage is a general term that can apply to animals feeding on forages, seedlings, or other woody vegetation. Browsing is a specific term that applies to vertebrate animals eating leafy shoots and twigs.

\section{$\underline{\text { Identification }}$}

Because vertebrates are often secretive and seldom seen, an untrained person may find it difficult to identify damage done by these animals. Therefore, it helps to know which ones occur in a given area and what "clues" they may leave behind. Good general guides include Murie (1974), Burt and Grossenheider (1976), and Peterson (1980).

To begin identifying damage, examine it. Is it below or above ground? Damage to roots or to stems close to the ground is limited to a few species. If below ground, is the damage associated with runways made by moles? Many small rodents, such as pocket gophers or pine voles, travel in mole runways and can severely damage roots. If above ground, how far above? Certain small mammals, notably cotton rats and rabbits, often damage small stems within $60 \mathrm{~cm}$ of the ground. Deer or domestic livestock may browse from ground level up to about 2 meters. Beavers may chew bark up to almost a meter, squirrels at any height. Table 1 will be useful in identifying animal damage to pines and other woody vegetation.

Visit the area where damage occurs at various hours to see and identify wildlife. Nighttime is a good time to look for mammals; early morning is prime time to observe birds feeding. Rake the earth smooth in selected areas so it will preserve tracks. Set mouse or rat traps to catch small mammals; peanut butter or moistened rolled oats make good bait. Freeze unfamiliar small mammals and get assistance in identifying them from a wildlife biologist. Be aware that some apparent "vertebrate damage" is actually due to insect pests. Get legal permission from state and federal wildlife agencies before collecting protected birds.

\section{CONTROL OPTIONS}

After identifying the pest, consider management options. The first is to do nothing. Is the damage serious? Is the animal a federally protected species? Are control permits required? Sometimes the extent of damage does not justify control. For example, sapsuckers may deface valuable trees but may cause no real threat to their existence or to seed or timber production. Often, however, damage by a single animal exceeds the acceptable economic threshold. For example, one beaver feeding in young pines along a creek or building a dam that could flood a large area may justify preemptive control with rifle or body-grip trap.

Wildlife management involves regulating the abundance of a certain species through two main approaches; (1) habitat management, which manipulates the animal's environment and (2) population management, which removes or protects animals. Both approaches often are necessary. For example, 
to control pine voles in a seed orchard or nursery, it is desirable to (1) minimize their habitat area by removing any mulch or vegetation near tree trunks and mowing grass closely and (2) reduce their population in remaining areas of thatch or brush by broadcasting zinc phosphide bait. In production stands, vole control is impractical.

Table 1. Identification of animal damage to woody vegetation in the Southeast

Location and description of damage.

\section{Chewing below ground}

Taproot chewed through. Chew marks about 1/16 in wide.

Taproot or other roots chewed through, or bark chewed off. Toothmarks very fine, about $1 \mathrm{~mm}$ or less

Stem girdling or debarking near the ground (within 4 feet)

Bark chewing up to $1 \mathrm{ft}$ above ground. Toothmarks less than $1 / 16$ in wide.

Bark chewed within $2 \mathrm{ft}$ from ground. In snow country, damage may be higher. Toothmarks $1 / 16-1 / 8$ in wide.

Bark or stem chewed within 2 in of ground. Toothmarks very fine, about $1 \mathrm{~mm}$ or less

Bark removed up to $3 \mathrm{ft}$ from ground. Lengthwise rub marks (antlers).

Bark removed up to $3 \mathrm{ft}$ above ground. Crosswise, parallel toothmarks $1 / 8-1 / 4$ in wide.

Irregular strips removed at base of saplings as a result of trampling. No toothmarks.

Branch girdling or debarking (usually 4 in or more above ground.

Irregular plates of bark removed, often measuring several inches on a side. Large toothmarks, few and scattered. Bark may be stripped from base due to inner bark feeding. Claw marks result from climbing.

Bark removed from trunks or branches, often at considerable heights.

Bark removed 2-8 $\mathrm{ft}$ above ground. Large, irregular toothmarks combined with stripping.

Bark removed from twigs in patches, or stems may be girdled. Chewing so fine that no toothmarks show.

\section{Branch or stem severing}

Shoots, saplings, or small trees cut off at base within $2 \mathrm{ft}$ of ground. Saplings cut off at an angle-larger trunks cut so as to leave a stump tapering to a point in the middle. Toothmarks $1 / 8-1 / 4$ in wide.

Twigs or branches found at water's edge with bark chewed off.

Twigs chewed off at sharp angle within 15 in off the ground. Toothmarks $1 / 16-1 / 8$ in wide.

Twigs broken or pulled off within $6 \mathrm{ft}$ of the ground; may be very close to the ground. Twigs do not show cut edges.

Twigs cut from high up in trees and found lying on the ground. Toothmarks $1 / 16-1 / 8$ in wide.

Leafy twigs of hickory or pecan cut neatly from high up in trees and lying on the ground. Cut ends show twig has been encircled by a $1 / 16$ in deep cut and the central part of the wood has broken off.

\section{Holes in tree trunks}

Small holes 1/4-1/2 in diameter in bark of live trees and arranged in horizontal lines (feeding injury).

Small holes as above in live or dead trees but randomly scattered (feed injury).

Round holes about 2 in diameter, in large, live pines (nesting cavity). Pecked area around hole oozes pitch.

Round holes $11 / 2-3$ in in diameter in dead or live trees (nesting cavity).

Vertical oval or rectangular holes $2 \times 4$ in or larger. Long, irregular $1-6$ in chips at base of tree.

Holes as above but chewed at edges by some other animal. (nesting cavity enlarged by squirrels).
Most likely animal pest

Pocket gopher

Geomys spp.

Pine vole (Orchard mouse)

Microtus pinetorum

Cotton rat

Sigmodon hispidus

Rabbit

Sylvilagus spp.

Pine vole (Orchard mouse)

$\underline{\mathrm{M}}$. pinetorum

Buck deer (fall and winter only)

Odocoileus virginianus

Beaver

Castor canadensis

Cattle

Black bear

$\underline{\text { Ursus americanus }}$

Squirrel

Sciurus spp.

Horse

European hornet (insect)

Often mistaken for vertebrate animal damage.

Beaver

C. canadensis

Beaver

C. canadensis

Rabbit

Sylvilagus spp.

Deer, cattle, horses

Squirrel

Sciurus spp.

Hickory Twig Girdler (insect)

Often mistaken for vertebrate

animal damage.

Yellow-bellied sapsucker (woodpecker)

Syphrapicus varius

Small woodpeckers (various species)

Red-cockaded woodpecker

Picoides borealis

Woodpeckers (various species)

Pileated woodpecker

Dryocopus pileatus

Woodpeckers (various species) 
Habitat management, where it works, may have longer lasting effects than population management. For instance, small rodents can reproduce or reinvade explosively in an ideal environment.

The following describes damage control options available to seed orchard, nursery, and forest managers for specific vertebrate pests. Currently, the single best source for further information about wildlife damage control is Timm (1983). Various sections of the volume edited by Timm describe damage control options for specific vertebrate pests that are available to seed orchard, nursery managers and forest managers.

\section{MAMMALS}

\section{Armadillos}

Armadillos may dig and burrow in soft earth in their search for insects and worms. These diggings can dislodge seedlings. Use a soil insecticide to remove insects and worms or use cage traps to remove the armadillos. Rotten bananas and slightly spoiled hamburger make good baits. Shooting with a 22 rifle or shotgun loaded with size 2 shot or larger is also effective.

\section{$\underline{\text { Moles }}$}

Moles may heave or dislodge seedlings by tunneling in seedling beds. Moreover, their burrows may harbor small rodents that feed on roots, stems, or seeds. But moles can be beneficial, too, by feeding on insects that may damage seedlings, including beetle larvae and mole crickets. Overall, they are not a problem in most forestry situations.

Moles reproduce very slowly in comparison with rodents. They typically have one litter of young per year and only a few young at a time. For this reason, mole traps are often effective. Both choker and harpoon types work well. To locate a good trap site, tread down runways in several places. Mark these spots. Repeat the process for a few days to locate places where burrows are reopened daily; set traps at these places.

Soil insecticides will reduce a mole's food supply and, eventually, the mole population; although the short-term result may be more tunneling because moles will have to burrow further to meet their food requirements. However, since these insecticides also kill beneficial organisms such as earthworms and some other soil invertebrates, removing the moles, rather than their food supply, is the better approach.

\section{Small Rodents}

Small rodents cause a variety of occasional and sporadic problems ranging from eating seeds to chewing stems and roots. Cotton rats, mice, and voles may eat seeds or damage seedlings. Cotton rats and pine voles may damage saplings as well.

To control small rodents, population and habitat should be managed in combination. Periodically trap rodent in snap traps. Eliminate weeds near seedbeds as well as mulch in problem areas; mow seed orchards closely. In outplanted areas, controlling weeds and planting less vulnerable largediameter seedlings can eliminate cotton rat damage.

Hawks and owls that prey upon small rodents can help significantly to manage rodent populations. Because predatory birds need a high vantage point from which to watch for prey, leave some tall trees or snags in areas to be planted to facilitate use by avian predators. Avoid shooting or trapping mammalian predators (such as foxes, bobcats, and coyotes) in areas where rodent control is a high priority.

Dry baits in the form of $2 \%$ zinc phosphide pellets are labeled for controlling pine voles and certain other mice. These may be handplaced near burrows or in runways, or broadcast on grassy or weedy areas. Do not broadcast this bait on bare ground because rodents are less likely to find it and it may poison birds. Repeat treatments are necessary, however, because rainy and damp conditions quickly deteriorate the pellets. For a review of vole control with baits, read Byers et al. (1982).

\section{Pocket Gophers}

Pocket gophers may girdle or completely clip small trees and damage roots of a wide variety of tree species. These rodents are usually confined to soils with a sandy or sandy loam A horizon. They make conspicuous mounds of soilhence their local southern name of "sandy mounder," which has been corrupted to "salamander" in many areas.

Pocket gophers are major problems where pastures and fields are converted to pines. They may be controlled by strychnine or zinc phosphide baits handplaced in burrows. If gophers are present in pastures intended for reforestation, gopher control is recommended before planting begins. Locate burrows by digging down at the mound to intersect the main tunnel. Place baits deep in the burrows; special probes for placing bait are commercially available. Then plug the tunnels with earth where they intersect the excavation.

\section{$\underline{\text { Squirrels }}$}

Fox squirrels ( $\underline{\text { Sciurus }} \underline{\text { niger})}$ and gray squirrels (․․ carolinensis) feed on cones, and both species, especially fox squirrels, will occasionally remove bark from large trees. Sometimes fox squirrels may remove plates of bark up to 10 x $30 \mathrm{~cm}$ near the tops of large $(25-\mathrm{m})$ pines. Squirrels are highly mobile and may cover a larger home range than other rodents or rabbits. Moreover, individuals from crowded populations short on food may travel for miles. Hence, removing a few animals may not stop the problem. Tree guards made from bands of metal $85 \mathrm{~cm}$ wide and wrapped to form a cylinder at head height on trunks will protect individual trees. Shooting may reduce populations in some cases. Box choker-type traps wired to tree trunks can be very effective. Use 2 or 3 traps per acre. Bait with nut meats or crusts of bread spread with peanut butter.

\section{$\underline{\text { Rabbits }}$}

A rabbit that has clipped seedlings usually lives close to the area where clipping damage is observed. For small areas, persistent shooting aided by a spotlight after dark will reduce rabbit populations. Wooden box traps left permanently in place will catch new arrivals; such traps are effective with or without bait.

For larger areas, broader measures are needed. Oneinch mesh-wire fence $85 \mathrm{~cm}$ high will keep rabbits out of a nursery. Site-preparation treatments that avoid debris piles but leave a few snags and isolated trees per hectare for birds of prey can be effective in preventing high rabbit populations from developing. Habitat management that reduces hiding cover and forage plants is probably the best approach on large tracts.

Deer

Deer trample seedbeds, browse seedlings, and rub their antlers on saplings. Single electric wire $85 \mathrm{~cm}$ high baited 
with a 50-50 slurry of peanut butter and vegetable oil marked with flagging, will keep most deer out (Hyngstrom and Craven 1988). Apply the peanut butter slurry with a paint roller. The most practical approach is population management through legal hunting or under authority of state game agencies by special permit. Plant large vigorous seedlings to increase their chances of surviving browsing. Where deer populations are high, delaying planting until spring foods have emerged may be a good strategy, although this may require using container seedlings.

Various repellents are labeled for use with deer and are of two types: (1) area repellents, which are sprayed on vegetation near the crop or applied to rags hung on posts or branches to give an unpleasant smell to deer, and (2) taste repellents, which are sprayed on the plant parts to be protected and which taste unpleasant to deer. Thiram and rotten-off solids are common ingredients in taste repellents. Repellents should be applied before deer discover seedlings. However, regardless of type, repellents provide partial and temporary protection at best.

\section{Domestic Grazing Animals}

Cattle, the most common domestic pest, trample and browse seedlings, and compact the soil where they tend to congregate. Domestic livestock may be fenced out much more easily than deer, but usually the problem is with the owner of the livestock.

Keep cattle out of newly regenerated areas for at least the first 1 or 2 years. Then permit grazing under a system in which the number of cattle and length of grazing on a site can be regulated. Locate feeding stations outside of planted areas if possible. Keeping cattle off bedded sites is a must because cattle will walk along bed tops during the wet months. On the other hand, subsoiled trenches on upland sites tend to protect seedlings because cattle prefer not to walk in subsoiled trenches.

Escaped domestic or feral hogs, which occasionally are a problem in newly planted stands and can severely damage orchards, nurseries, and progeny test plots, may be removed with special box traps or gated enclosures. Where legal, no. 4 leghold traps will catch feral hogs; however, this size trap is illegal for upland use in some states. Do not use these large traps on lands that are not under strict control. Stake the traps securely or fasten them to heavy drags. Set traps in known trailways or bait hogs to trap locations with corn, table scraps, or other food.

Birds

In nurseries, bird species may eat sown seed or pluck the tops off seedlings after they have emerged but while the endosperm is still attached. This is a serious problem because genetically improved seed is expensive.
Make sure the sowing technique covers the seed. Sowing seeds treated with Thiram is also effective. Other seed treatments (e.g., methiocarb) are labeled for protecting planted corn from bird damage, but there has been no research on their efficiency on pine seeds. In addition sowing with stratified seed under conditions favorable for rapid germination will minimize the vulnerable time of seed.

Various scaring devices such as regular or "cracker" shells, acetylene or gas exploders, fireworks, or other pyrotechnic devices, may provide short-term protection of seedbeds from flocks of seed-eating birds. However, these devices need regular attention. They should be relocated periodically and combined with human activity to be most effective. Otherwise, birds will soon learn to ignore the sound.

Netting, while often scorned as too costly or impractical, is a viable solution to some bird damage problems. In some states (California, in particular), vast areas of small fruits are protected with removable netting that is reused annually.

\section{ACKNOWLEDGMENTS}

We thank Gary De Barr (USDA Forest Service) and John Godbee (Union Camp Corporation) for their briefing on certain wildlife pest problems of seed orchards and nurseries; and Phil Dougherty, Syd Johnson, and Tony Melchiors for helpful comments on the manuscript .

\section{LITERATURE CITED}

BURT, W., and R. P. GROSSENHEIDER. 1976. A Field Guide to the Mammals. Peterson Field Guide Series. Houghton Mifflin Company, Boston, MA. 289 pp.

BYERS, R. E., M. H. MERSON, and S. D. PALMATEER. 1982. Control of orchard voles with broadcast baits. J. Amer. Soc. Hort. Sci.107(4):613-619.

HYNGSTROM, S. E., and S. R. CRAVEN. 1988. Electric fences and commercial repellents for reducing deer damage in cornfields. Wildl. Soc. Bull. 16:291-296.

JACKSON, J. 1984. Controlling vertebrate animal damage in forest nurseries and seed orchards in the southeast. Pages 195-203 In: Proc. Integrated Forest Pest Management Symposium. Athens, GA.

MURIE, J. 1974. A Field Guide to Animal Tracks. Peterson Field Guide Series. Houghton Mifflin Company, Boston, MA. 375 pp.

PETERSON, T. 1980. A Field Guide to the Birds East of the Rockies. Peterson Field Guide Series. Houghton Mifflin Company, Boston, MA 384 pp.

TIMM, M. (Ed.) 1983. Prevention and control of wildlife damage. Great Plains Agric. Council Wildlife Resources Committee and Nebraska Coop. Extension Serv., Univ. of Nebraska, Lincoln. 640 pp. 